Thorax (1949), 4, 44.

\title{
THE PULMONARY COMPLICATIONS OF DYSPHAGIA
}

\author{
BY \\ J. R. BELCHER \\ Hospital for Consumption and Diseases of the Chest, London
}

\section{INTRODUCTION}

This paper is concerned with the pulmonary - aspiration phenomena associated with mechanical dysphagia, and the term "dysphagia pneumonitis" is used for the syndrome. Lesions due to central dysphagia and secondary to bronchooesophageal fistulae have been excluded. In 1927 Vinson reported a case of achalasia which was complicated by a lung abscess, and since then 38 others have been described. These, together with a further collection of nine cases hitherto unpublished, form the basis of this article.

After Vinson's paper the majority of reports in the 1930's were published by French otolaryngologists as single unusual histories. But from 1938 onwards more have appeared in the American literature, some have been described by clinicians, and others by radiologists. Weens (1944) collected five and reviewed the literature, BirdAcosta (1944) described a further three, and Hawes and Soule (1945) two cases. Six have been published in the British journals by Cummins and Williams (1933), Schrier (1938), Robson and Wilkinson (1946), and Wooler (1948); others have been described incidentally in reviews of different conditions. Jackson and Jackson (1933), in discussing pulmonary symptoms of oesophageal disease, cite three cases, and Keefer (1934) reported one aspiration lung abscess in a paper describing seventeen examples of oesophageal carcinoma associated with pulmonary lesions. Harrington (1945) and Lahey (1946), in their large series of pharyngeal diverticula, each mention four cases complicated by lung abscesses.

The association of dysphagia with the presence of non-pathogenic acid-fast bacilli in the sputum and with lipoid pneumonia has led to the publication of a further six cases (Rothstein and Pirkle, 1946 ; Baldwin, 1942 ; Thomas and Jewett, 1936 ; Warring and Rilance, 1943 ; Cummins and Williams, 1933 ; Tcherthoff, 1941), and Wooler (1948), in his paper on cardiospasm, refers to three examples of "dysphagia pneumonitis."

\section{CASe Histories}

The summaries of the nine cases given below include examples of the main causative factors and of the commoner resulting pulmonary lesions.

Case 1. Achalasia complicated by collapse.-A woman aged 65 had thirteen years' history of dysphagia due to achalasia. She was investigated in November, 1947, and a gross mega-oesophagus was discovered (Plate Ia). In January, 1948, she was admitted to hospital with three weeks' history of productive cough, fever, and dyspnoea. A radiograph (Plate $\mathrm{I} b$ ) showed a collapsed right lower lobe. Her clinical condition improved and an oesophagogastrotomy was performed (N. R. Barrett) in March, 1948. The operation was complicated by total atelectasis on the right side. The upper lobe reexpanded after aspiration of food particles through a bronchoscope, but the lower lobe collapse persisted.

Case 2. Achalasia complicated by pneumonitis with acid-fast bacilli in sputum.-A man aged 41 , from 1940 to 1945 complained of slight dysphagia on hurrying food. In 1945 he developed "pneumonia." Acidfast bacilli were found in the sputum. A radiograph (Plate II $a$ ) showed bilateral mid-zone infiltration with a suggestion of cavitation on the right side. Rapid clinical and radiological improvement ensued until his radiograph was almost clear six months later. In March, 1948, a Heller's operation was performed $\frac{7}{0}$ (N. R. Barrett) for increasing dysphagia. He had no pulmonary symptoms in the interim, the radiograph $N$ was then clear (Plate II $b$ ) and no acid-fast bacilli were found in his oesophagus or sputum.

Case 3. Achalasia associated with "typical" fibrosis. - A man aged 50, whose abnormality was discovered on mass radiography (Eley, 1948), had had o slight dysphagia for years with recent dyspnoea and $\overparen{D}$ repeated bronchitis. The radiograph (Plate III $a$ ) is $\stackrel{9}{?}$ characteristic of the condition; this and his symptoms 0 have now remained unchanged for a year.

Case 4. Carcinoma of lower third of oesophagus $\mathbb{D}$ and lung abscess. - A man aged 69 gave a three weeks' $\mathbb{D}$ history of cough and purulent sputum. A radiograph $\varrho$ showed a left dorsal-lobe lung abscess with a fluid level. He improved until he was symptom-free one o month later. The radiograph now showed no cavity, 
but there was residual fibrosis in the fissure area. Two months later his dysphagia became overt and a barium swallow and oesophagoscopy revealed a carcinoma of the lower third of the oesophagus. There was no evidence of a fistula.

Case 5. Pharyngeal diverticulum with patchy pneumonitis. - A man aged 65 who had had bronchitis for years developed " pneumonia" eight years ago and had had repeated attacks since then. He also noticed dysphagia for six to eight years, which was getting gradually worse. In August, 1947, he developed a patch of infiltration at the apex of his right lung, and acid-fast bacilli were found in the sputum on one occasion. The symptoms cleared rapidly, but the pneumonia recurred in December, 1947; he has remained sputum-negative since then. His diverticulum was excised in June, 1948 (C. Price Thomas). His bronchitis persists, but there are no other symptoms, and the infiltration in the radiograph is now clearing.

Case 6. Pharyngeal diverticulum with lung abscess. -A man aged 46 complained of one year's history of dysphagia. In September, 1947, he developed pneumonia, and two months later during a second attack he was diagnosed as having a lung abscess. He was admitted to hospital in January, 1948, and was shown to have a pharyngeal diverticulum associated with a left upper-lobe lung abscess and collapse of the left lower lobe. One month later he developed a patch of "pneumonitis" in the right lower lobe which cleared with chemotherapy. His general condition improved, and the radiograph cleared, but the left lower lobe collapse persisted. In February, 1948, the pouch was excised and he was discharged much improved one month later. At that time the collapse and abscess had cleared, leaving areas of pulmonary fibrosis.

Case 7. "Short" oesophagus associated with bilateral bronchiectasis.-A child aged 6 gave a history of frequent coughs, colds, and pain in chest since the age of 1 year. She had "pneumonia" when aged 2 years and 3 years, and thereafter continuous nonfoetid sputum. She was investigated in 1945 and found to have almost total bronchiectasis on the right side. She was seen again six months later when she had started "vomiting" white phlegm and was not gaining weight. Another bronchogram at this time showed lingular bronchiectasis. One year later the vomiting was much worse and a barium swallow showed dilated "short" oesophagus, probably secondary to peptic ulceration.

Case 8. Achalasia in association with pulmonary fibrosis.-A man aged 35 who had had an empyema drained in 1930 developed " influenza " in November, 1940. He was investigated in 1941 and found to have mega-oesophagus secondary to achalasia and bilateral mid-zone infiltration of the lungs. During the next two years the infiltration waxed and waned on alternate sides due to recurrent attacks of "pneumonitis." In January, 1943, he was admitted to hospital with a history of occasional haemoptyses, minimal cough, and regurgitation. Clubbing was present. The radiograph (Plate III $b$ ) shows mid-zone shadows and a mega-oesophagus. The achalasia was treated by dilatation of the cardia with a hydrostatic bag. The lung fields remained unchanged on radiography, but the oesophageal dilatation was improved.

Case 9. Achalasia associated with lipoid pneumonia.-A woman aged 19 complained of three years' history of sickness after meals. Bougies were passed at intervals with partial improvement for one year. She then developed rheumatism in the hands, and radiograph of the chest showed "abnormality secondary to dysphagia." Two years later radiography showed lipoid pneumonia (Plate IVa), and bouginage was continued. One year later, in 1945, a Heller's operation was performed. The diagnosis of lipoid pneumonia was made from the radiographs and from a history of inhalation of liquid paraffin.

\section{Discussion}

INCIDENCE.-The frequency with which pathological conditions of the oesophagus are associated with abnormalities of the lungs is difficult to assess; there is little doubt that it is considerably greater than the number of cases recorded in the literature suggest. Weens (1944) found that in his series of fifteen cases of achalasia of the cardia, five developed pulmonary lesions, but-Eley (1948) only found one example in 60,000 mass radiographs. The eight patients described by Harrington (1945) and Lahey (1946) give an accurate idea of the incidence in their series of 349 pharyngeal diverticula.

AETIOLOGY.-The pulmonary changes associated with dysphagia are due to aspiration of oesophageal contents into the bronchial tree. The mechanism of aspiration varies with different oesophageal lesions. During normal deglutition the arrival of a bolus of food in the pharynx sets up a reflex mechanism, part of which is concerned with the onwards transmission of the food, and part of which prevents its ingress through the glottis. A lesion which interferes with this protective reflex makes aspiration almost inevitable. When deglutition is not taking place the cough reflex protects the bronchial tree from contamination by liquid in the pharynx or oesophagus. Any lesion which may cause the retention of liquid in this area, in the presence of factors which tend to dull the cough reflex, renders the patient liable to "dysphagia pneumonitis."

Carcinomata of the upper third of the oesophagus are particularly prone to produce aspiration, as they are usually of the stenotic type causing early dysphagia, and are often compli- 
cated by recurrent nerve palsies. This combination provides the factors of retention of liquid in the pharynx plus interference with the mechanism normaly responsible for closure of the glottis during deglutition. Camiel and Loewe (1941) divided their cases of carcinoma of the oesophagus into upper-third and lower two-thirds groups, for the purpose of discussion of pulmonary complications. They demonstrated that cases in the upper third almost invariably died of aspiration pneumonia (eleven cases out of thirteen) secondary to vocal-cord paralysis. They demonstrated the "spill" in progress during a barium swallow, and considered that it would be possible to do this in all cases of upper-third carcinoma with vocal-cord paralysis. The remaining seventeen cases in their series were in the lower two-thirds of the oesophagus, and of these only two gave rise to "dysphagia pneumonitis."

The two conditions most frequently responsible for the presence of retained liquid in the pharynx are achalasia of the cardia and pharyngeal diverticulum. Even in advanced cases of megaoesophagus secondary to achalasia the column of fluid seldom reaches the glottis when the patient is in the upright position, and thus it is only liable to be aspirated in recumbency. There are cases on record of patients who had to sleep in - the upright position to prevent the choking caused by recumbency (Grey Turner, 1946). The fact that regurgitation occurs under these conditions may be due, as has been suggested by Negus (1942), to incompetence of the cricopharyngeal sphincter.

The method by which the contents of the pharyngeal pouches get into the danger area is probably different. Alteration in position of the head from side to side may squeeze the retained contents of the pouch into the pharynx; during the daytime gravity carries the material away from the glottis, but during sleep it flows upwards.

Sergent and others (1934) produced an hypothesis to account for loss of the normal protective reflex of the glottis. They described a patient who was found to have barium in his right lower lobe after a barium swallow. The patient had been unaware of the passage of liquid into his bronchial tree. These authors suggested that repeated small " insults" dulled the normal reflex and gave rise to aspiration during deglutition.

Brock (1946) explains the predilection of lung abscess for the upper lobes by stating that bronchial embolism occurs when the cough reflex is diminished during sleep, recumbency and gravity being responsible for the position of the abscesses. A large proportion of the cases in $\frac{0}{0}$ his series had upper-lobe disease.

Anaesthesia also causes abolition of the cough $\frac{\bar{c}}{\frac{\bar{p}}{7}}$ reflex. Post-operative bronchial embolism may $\mathbb{\Phi}$ be due to material aspirated from the oesophagus as well as from the much more common sites above the glottis. This occurred in Case 1, in which the right upper-lobe collapse was due to $\overrightarrow{\vec{\omega}}$ aspiration of oesophageal contents either during $\stackrel{\omega}{\omega}$ or soon after operation.

Price Thomas (1948) suggests that in order to diminish the risk of aspiration in the preoperative period the pouch or oesophagus should $f$ be cleansed with sodium bicarbonate and then 을 emptied by the patient tipping head downwards just before retiring. Emptying the "sump" immediately pre-operatively, either by this method or by oesophagoscopy as practised by Allison, $\stackrel{5}{\Im}$ seems a wise precaution.

\section{Pathology}

General.-Certain aspects of the pathology of the pulmonary lesions secondary to the aspiration of oesophageal contents differ from those secondary to aspiration from the upper respiratory $\frac{\circ}{\Phi}$ tract and mouth. There are two reasons for this: $\varrho$ the aspirations of oesophageal contents frequently $\overrightarrow{\vec{O}}$ take the form of repeated small insults to the 3 bronchial tree, rather than of large "spills" ; and secondly the material aspirated is less liable to contain pathogenic organisms. Where there is ulceration of the oesophageal lesions, as in the $\frac{\mathrm{O}}{\mathrm{T}}$ case of carcinomata, pulmonary complications $x$ occur earlier than in achalasia where ulceration $\frac{3}{3}$ is a late and inconstant feature.

The pulmonary lesions with which the patients have presented in this series have been as follows:

$\begin{array}{lrrrr}\text { Lung abscess } & & \ldots & \ldots & 18 \\ \text { Bronchiectasis } & & \ldots & \ldots & 6 \\ \begin{array}{l}\text { Fibrosis } \\ \text { "Lipoid pneumonia }\end{array} & \ldots & \ldots & 10 \\ \text { “Pneumonitis" } & \ldots & \ldots & 4 \\ \text { Collapse } & \ldots & \ldots & \ldots & 8 \\ & & & \\ & \text { Total } & & & 48 \\ \end{array}$

As the aetiology of these lesions is fundamentally the same, no hard-and-fast line should be drawn between them; each is a manifestation of an incident in the course of the disease. As pul- $\frac{}{\Phi}$ monary abscess formation is the most serious? complication, the largest number of cases were 0 discovered at this stage. At least five of these abscesses gave rise to residual fibrosis, and two patients who were discovered at the stage of 
TABLE I

SUMMARY OF HISTORIES OF PATIENTS WITH PNEUMONITIS

\begin{tabular}{|c|c|c|c|c|c|c|c|}
\hline Author & Age & Sex & Cause & Effect & Site & $\begin{array}{l}\text { Course } \\
\text { and } \\
\text { comments }\end{array}$ & Presentation \\
\hline $\begin{array}{l}\text { Cummins and } \\
\text { Williams }\end{array}$ & 30 & F & & & Right & $\begin{array}{l}\text { Acid-fast bac- } \\
\text { illi, clubbing }\end{array}$ & Dysphagia \\
\hline Bird-Acosta . : & 58 & $\mathbf{M}$ & Achalasia & Pneumonitis & $\begin{array}{l}\text { 2nd and 5th } \\
\text { right inter- } \\
\text { space }\end{array}$ & $\begin{array}{l}\text { Cleared com- } \\
\text { pletely }\end{array}$ & $\begin{array}{l}\text { Recurrent } \\
\text { pneumonia }\end{array}$ \\
\hline $\begin{array}{l}\text { Weens } \\
\text { Jackson }\end{array}$ & $\begin{array}{l}18 \\
42\end{array}$ & $\begin{array}{l}\mathbf{F} \\
\mathbf{M}\end{array}$ & $\begin{array}{l}\text { Achalasia } \\
\text { Achalasia }\end{array}$ & $\begin{array}{l}\text { Pneumonitis } \\
\text { Pneumonitis }\end{array}$ & $\begin{array}{l}\text { Both tases } \\
\text { Right lower } \\
\text { lobe }\end{array}$ & $\begin{array}{l}\text { Cleared } 1 \text { year } \\
\text { Cleared }\end{array}$ & $\begin{array}{l}\text { Dysphagia } 2 \text { years } \\
\text { Dysphagia, regurg- } \\
\text { tation, cough, and }\end{array}$ \\
\hline Jackson & $1 \frac{1}{2}$ & F & Stricture & Pneumonitis & Diffuse & $\begin{array}{l}\text { Cleared com- } \\
\text { pletely }\end{array}$ & $\begin{array}{l}\text { Regurgitation and } \\
\text { cough since birth }\end{array}$ \\
\hline Tucker & 13 & $\mathbf{M}$ & Achalasia & Pneumonitis & $\begin{array}{c}\text { Right upper } \\
\text { lobe }\end{array}$ & $\begin{array}{l}\text { Cleared com- } \\
\text { pletely }\end{array}$ & Chronic cough \\
\hline Wooler & 16 & $\mathbf{F}$ & Achalasia & $\begin{array}{l}\text { Collapse with } \\
\text { pneumonitis }\end{array}$ & $\begin{array}{l}\text { Right mid-zone } \\
\text { and right } \\
\text { lower lobe }\end{array}$ & $\begin{array}{l}\text { Minimal dys- } \\
\text { phagia }\end{array}$ & $\underset{\text { ptysis }}{\text { Cough }}$ haemo- \\
\hline Case 2 & 41 & $\mathbf{M}$ & Achalasia & Pneumonitis & $\begin{array}{c}\text { Mid-zones max- } \\
\text { imal on right }\end{array}$ & $\begin{array}{l}\text { Acid-fast bac- } \\
\text { illi, cleared }\end{array}$ & Pneumonia \\
\hline Case 5 & 65 & $\mathbf{M}$ & Diverticulum & Pneumonitis & $\begin{array}{l}\text { Right second } \\
\text { inter-space }\end{array}$ & $\begin{array}{l}\text { Acid-fast bac- } \\
\text { illi, cleared }\end{array}$ & $\begin{array}{l}\text { Dysphagia and re-- } \\
\text { current pneumonia } \\
8 \text { years }\end{array}$ \\
\hline
\end{tabular}

fibrosis gave histories suggestive of abscess formation.

Tracheo-bronchitis. - This lesion can cause recurrent cough long before the development of frank pulmonary lesions, and a low-grade tracheo-bronchitis is inevitable whenever irritating material is repeatedly aspirated in small quantities. This is responsible for the long-standing cough often associated with dysphagia. It has been mentioned specifically by Jackson and Jackson (1933) and by Tucker (1933); the former authors proved the presence of tracheo-bronchitis on bronchoscopy.

"Pneumonitis."-The term "dysphagia pneumonitis" is used in the broad sense to cover all pulmonary lesions associated with dysphagia. In this section "pneumonitis" is taken to mean non-specific inflammation of the interstitial tissue of the lung; it has occurred as a separate entity and also in association with fibrosis (Case 8) and with lung abscesses (Case 6). In nine cases (three of which were associated with acid-fast bacilli in the sputum) it has presented as a separate entity, and the impression given by the histories is that the aspirations responsible were minimal, sporadic, and of short duration (as in Case 2).

"Pneumonitis" has been mentioned as occurring in association with fibrosis on five occasions. It cleared subsequently and must have been due to an exacerbation of the process causing the fibrosis. The features common to these patients were that they all cleared up completely, some after treatment of their dysphagia, and all had had single or recurrent attacks of "pneumonia " with fever, cough, sputum, and pain in the chest. The distribution of the lesions was predominantly right-sided and in the mid-zones. The original radiograph of Case 2 is similar to those published by Warring and Rilance, both of whose patients went on to fibrosis. In Case 2 complete clearing took place, and the relative shortness of history and paucity of symptoms accounts for this difference, although it is possible that in all cases of "pneumonitis" some degree of fibrosis takes place, but that only in old-standing ones is it sufficiently dense to be radio-opaque.

Pulmonary abscess.-A major spill of material from the oesophagus, in some cases containing virulent organisms, is the probable cause of development of pulmonary abscesses. Of the eighteen cases collected in this series three have been multiple and ten have been described as foetid. The localization of the lung abscesses has been as follows:

\begin{tabular}{|c|c|c|}
\hline Right upper lobe & & \\
\hline Right middle lobe & & \\
\hline $\begin{array}{l}\text { Right lower lobe } \ldots \\
\text { Left upper lobe }\end{array}$ & & \\
\hline $\begin{array}{ll}\text { Left } \\
\text { Left lower lobe } & \ldots\end{array}$ & $\cdots$ & $\cdots$ \\
\hline
\end{tabular}

Of those occurring in the lower lobes four have been in the apical segments; that is, of the total twenty abscesses in eighteen cases, sixteen have occurred in the sites most liable to bronchial embolus during recumbency.

The positions in which a group of patients slept were recorded twice a night in order to see whether 
TABLE II

SUMMARY OF HISTORIES OF PATIENTS WITH PULMONARY ABSCESS

\begin{tabular}{|c|c|c|c|c|c|c|c|}
\hline Author & Age & Sex & Cause & Effect & Site & $\begin{array}{l}\text { Course } \\
\text { and } \\
\text { comments }\end{array}$ & Presentation \\
\hline Vinson & 42 & $\mathbf{M}$ & Achalasia & Putrid abscess & Right upper & Fibrosis & 10 years' dysphagia \\
\hline Sampson & 40 & $\mathbf{M}$ & Achalasia & Putrid abscess & $\begin{array}{l}\text { Right upper } \\
\text { lobe }\end{array}$ & $\begin{array}{l}\text { Asymptomatic; } \\
\text { lung stone }\end{array}$ & Lung abscess \\
\hline $\begin{array}{l}\text { Rothstein and } \\
\text { Pirkle }\end{array}$ & 41 & $\mathbf{F}$ & Achalasia & Abscess & $\begin{array}{l}\text { Right upper } \\
\text { lobe; left lower } \\
\text { lobe }\end{array}$ & $\begin{array}{l}\text { Acid-fast bac- } \\
\text { illi, fibrosis }\end{array}$ & $\begin{array}{l}10 \text { years' dysphagi } \\
\text { and regurgitation }\end{array}$ \\
\hline Keefer & 63 & $\mathbf{M}$ & $\begin{array}{l}\text { Carcinom a } \\
\text { upper one } \\
\text { third }\end{array}$ & Abscess & $\begin{array}{l}\text { Right upper } \\
\text { lobe }\end{array}$ & $\begin{array}{l}\text { No full des- } \\
\text { cription }\end{array}$ & Dysphagia \\
\hline Baldwin & 24 & F & Achalasia & Abscess & $\begin{array}{l}\text { Right upper } \\
\text { lobe }\end{array}$ & $\begin{array}{l}\text { Acid-fast bac- } \\
\text { illi, fibrosis }\end{array}$ & $\begin{array}{l}\text { Dysphagia and } \mathrm{re} \\
\text { gurgitation }\end{array}$ \\
\hline Weens & 29 & $\mathbf{M}$ & Achalasia . & Foetid abscess & $\begin{array}{l}\text { Right upper } \\
\text { lobe }\end{array}$ & $\begin{array}{l}10 \text { years mini- } \\
\text { mal dyspha- }\end{array}$ & Lung abscess \\
\hline Bird-Acosta . . & 53 & $\mathbf{F}$ & Achalasia & Foetid abscess & $\begin{array}{l}\text { Right dorsal } \\
\text { lobe }\end{array}$ & Fibrosis & 10 years' dysphagi \\
\hline $\begin{array}{l}\text { Lallemant and } \\
\text { Ordioni }\end{array}$ & 38 & F & Achalasia & $\begin{array}{l}\text { Non-foetid ab- } \\
\text { scess }\end{array}$ & $\begin{array}{l}\text { Right upper } \\
\text { lobe }\end{array}$ & $\begin{array}{l}\text { "Silent" dys- } \\
\text { phagia }\end{array}$ & Lung abscess \\
\hline Sergent $\quad \ldots$ & 64 & $\mathbf{M}$ & Stricture & Foetid abscess & $\begin{array}{l}\text { Right upper } \\
\text { lobe }\end{array}$ & $\begin{array}{c}20 \text { years bron- } \\
\text { chitis, cleared }\end{array}$ & Dysphagia 9 years \\
\hline Sergent & 45 & $\mathbf{M}$ & $\begin{array}{c}\text { Carcinoma } \\
\text { upper third }\end{array}$ & Foetid abscess & $\begin{array}{l}\text { Right upper } \\
\text { lobe }\end{array}$ & No fistula & $\begin{array}{l}\text { Dysphagia ; shor } \\
\text { history }\end{array}$ \\
\hline Mallory & 64 & $\mathbf{M}$ & $\begin{array}{l}\text { Achalasia and } \\
\text { carcinoma }\end{array}$ & Foetid abscess & $\begin{array}{l}\text { Right lower } \\
\text { lobe }\end{array}$ & 15 years' cough & $\begin{array}{l}\text { Dysphagia } 15 \text { year } \\
\text { and regurgitation }\end{array}$ \\
\hline $\begin{array}{l}\text { Pruvost and } \\
\text { Leblanc }\end{array}$ & 48 & $\mathbf{M}$ & Diverticulum & Foetid abscess & $\begin{array}{l}\text { Right upper } \\
\text { lobe }\end{array}$ & $\begin{array}{l}\text { Cleared com- } \\
\text { pletely }\end{array}$ & Lung abscess \\
\hline $\begin{array}{l}\text { Chabrol and } \\
\text { Cachin }\end{array}$ & ? & $?$ & Achalasia & Chronic abscess & $\begin{array}{l}\text { Left dorsal } \\
\text { lobe }\end{array}$ & $\begin{array}{l}\text { Recurrent pro- } \\
\text { ductive cough }\end{array}$ & Dysphagia 16 year \\
\hline Sergent & $?$ & F & Diverticulum & Foetid abscess & $\begin{array}{l}\text { Right lower } \\
\text { lobe }\end{array}$ & Cleared up & Lung abscess \\
\hline Walle & 7 & $\mathbf{M}$ & Stricture & Foetid abscess & $\begin{array}{l}\text { Right upper } \\
\text { lobe, right } \\
\text { dorsal }\end{array}$ & Cleared up & $\begin{array}{l}\text { Dysphagia and re } \\
\text { gurgitation }\end{array}$ \\
\hline Jackson & 44 & $\mathbf{M}$ & Stricture & Foetid abscess & $\begin{array}{l}\text { Right lower } \\
\text { lobe }\end{array}$ & Cleared up & $\begin{array}{l}\text { Broncho- } \\
\text { pneumonia }\end{array}$ \\
\hline $\begin{array}{l}\text { Case } 6 \\
\text { Case } 4\end{array}$ & $\begin{array}{l}46 \\
69\end{array}$ & $\begin{array}{l}\mathbf{M} \\
\mathbf{M}\end{array}$ & $\begin{array}{l}\text { Diverticulum } \\
\text { Carcinoma } \\
\text { lower third }\end{array}$ & $\begin{array}{l}\text { Abscess collapse } \\
\text { Abscess }\end{array}$ & $\begin{array}{l}\text { Left upper lobe } \\
\text { Left dorsal lobe }\end{array}$ & $\begin{array}{l}\text { Fibrosis } \\
\text { Cleared-fib- } \\
\text { rosis-" "sil- } \\
\text { ent" d y s- } \\
\text { phagia }\end{array}$ & $\begin{array}{l}\text { Dysphagia } 1 \text { year } \\
\text { Lung abscess }\end{array}$ \\
\hline
\end{tabular}

the predominance of right-sided lesions could be accounted for by gravity. The results were as follows :

$\begin{array}{lllll}\text { Right side } & \ldots & \ldots & \ldots & 579 \\ \text { Left side } & \ldots & \ldots & \ldots & 429 \\ \text { Back } \ldots & \ldots & \ldots & \ldots & 302\end{array}$

The straightness of the right main bronchus tends to make aspirated material go to the right side when the patient lies on his back, and thus lesions on the right side should be twice as common as those on the left. In fact the proportion is higher.

In this series not one of the pulmonary abscesses had to be drained; of those in which details were given, three died, five led to fibrosis with disappearance of the cavity (Case 4), two led to chronic abscesses (one with a "lung stone" but no sympi toms), and five cleared up completely. The clinicallo course is different from the other types of aspiration abscess in which chronicity is so much more commons

Abscess formation is an incident in the course of the disease. Where there has been a very long histor the likely end result will be fibrosis ; where the history has been short complete clearing appears to be more likely.

Pulmonary fibrosis.-A prolonged series of aspira⿳亠 tions extending over many years gives rise to pulo monary fibrosis, and it is the most frequent end resulf of dysphagia pneumonitis. Ten cases were first diag nosed at this stage, and five of the pulmonary abscesses 


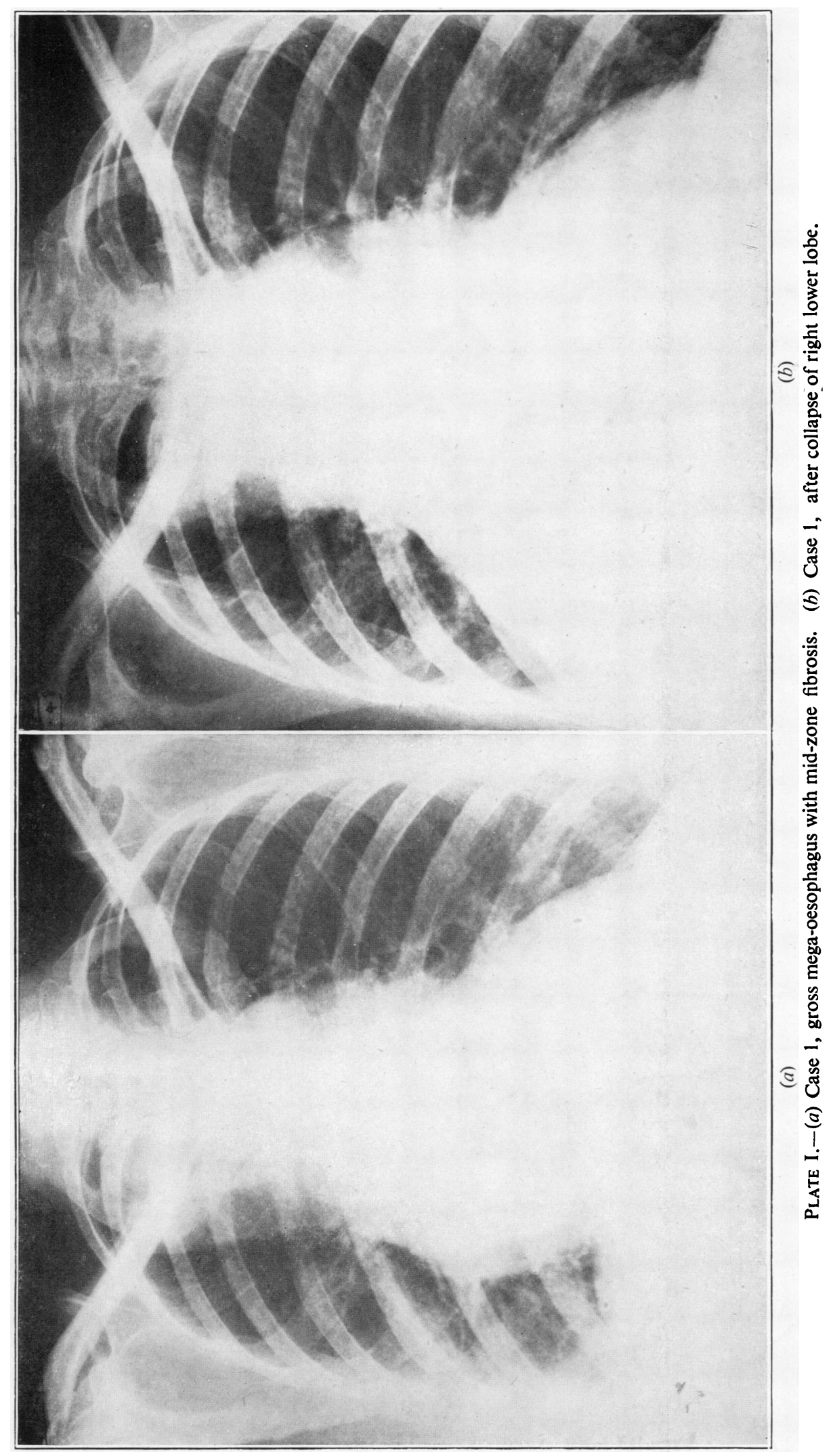

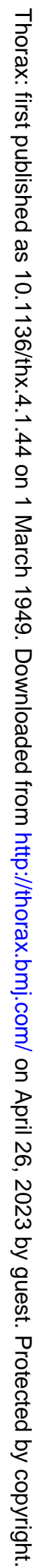




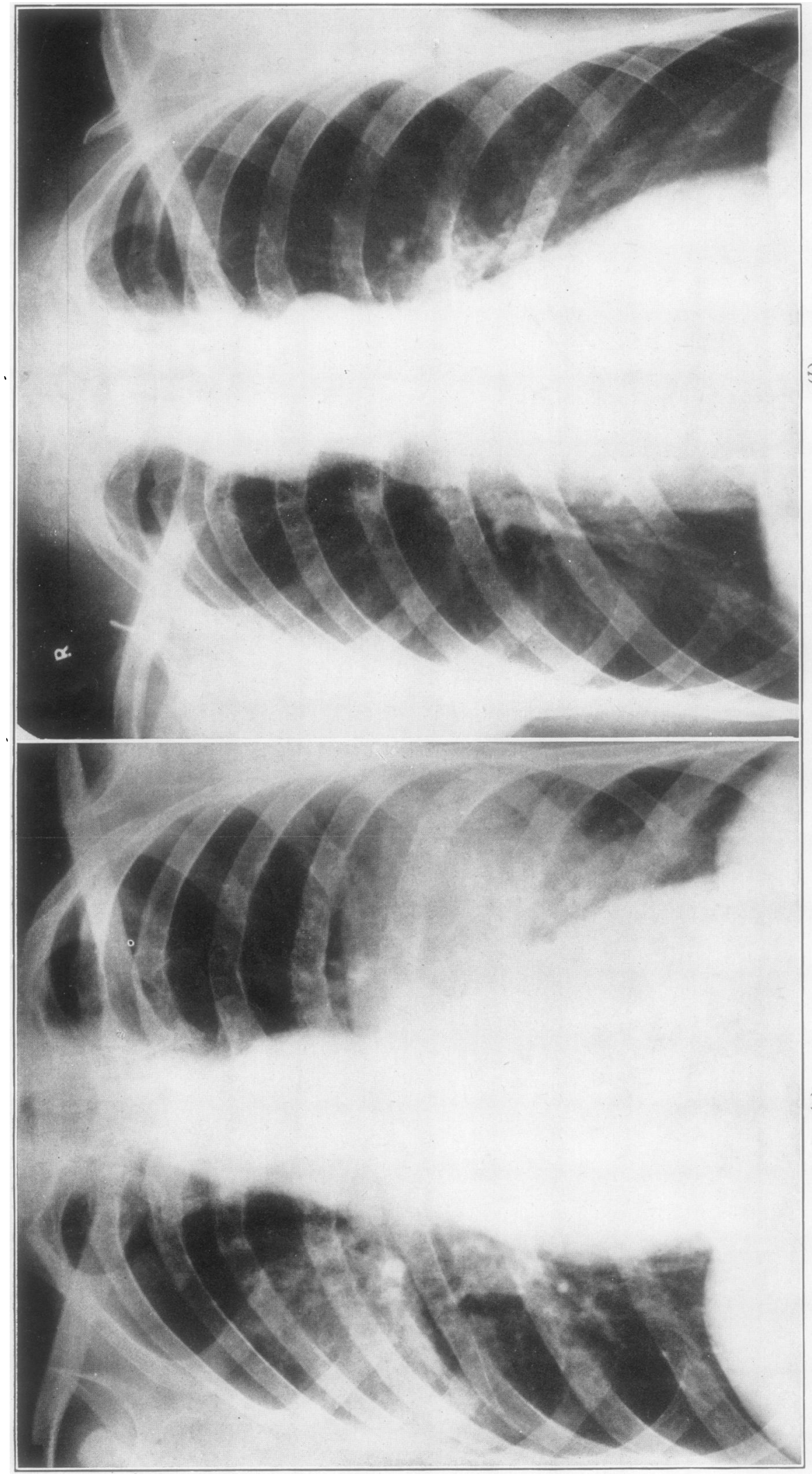

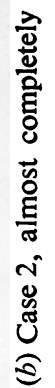

2 $\frac{\dot{0}}{2}$

롱

ธี

䒿

4

옴

品

क्ज

壱总

혼ㅎㅀㄴ

壱

商

몸

팸

苟

돌

हू

(อ)

\&

宊

ヘิ

है

览

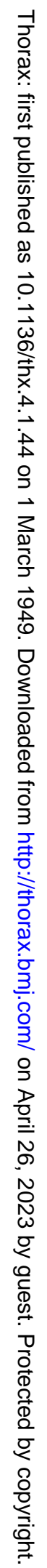




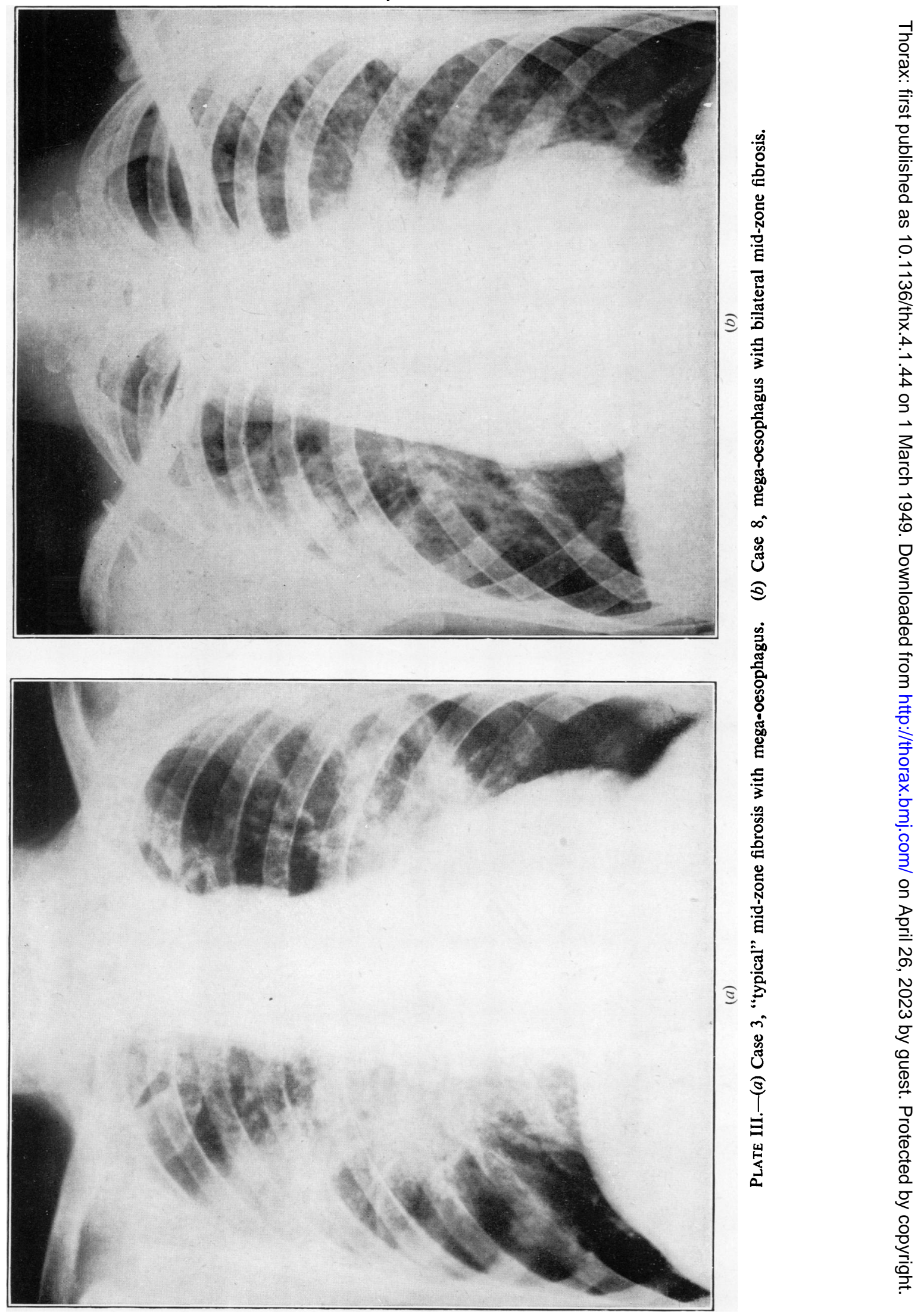



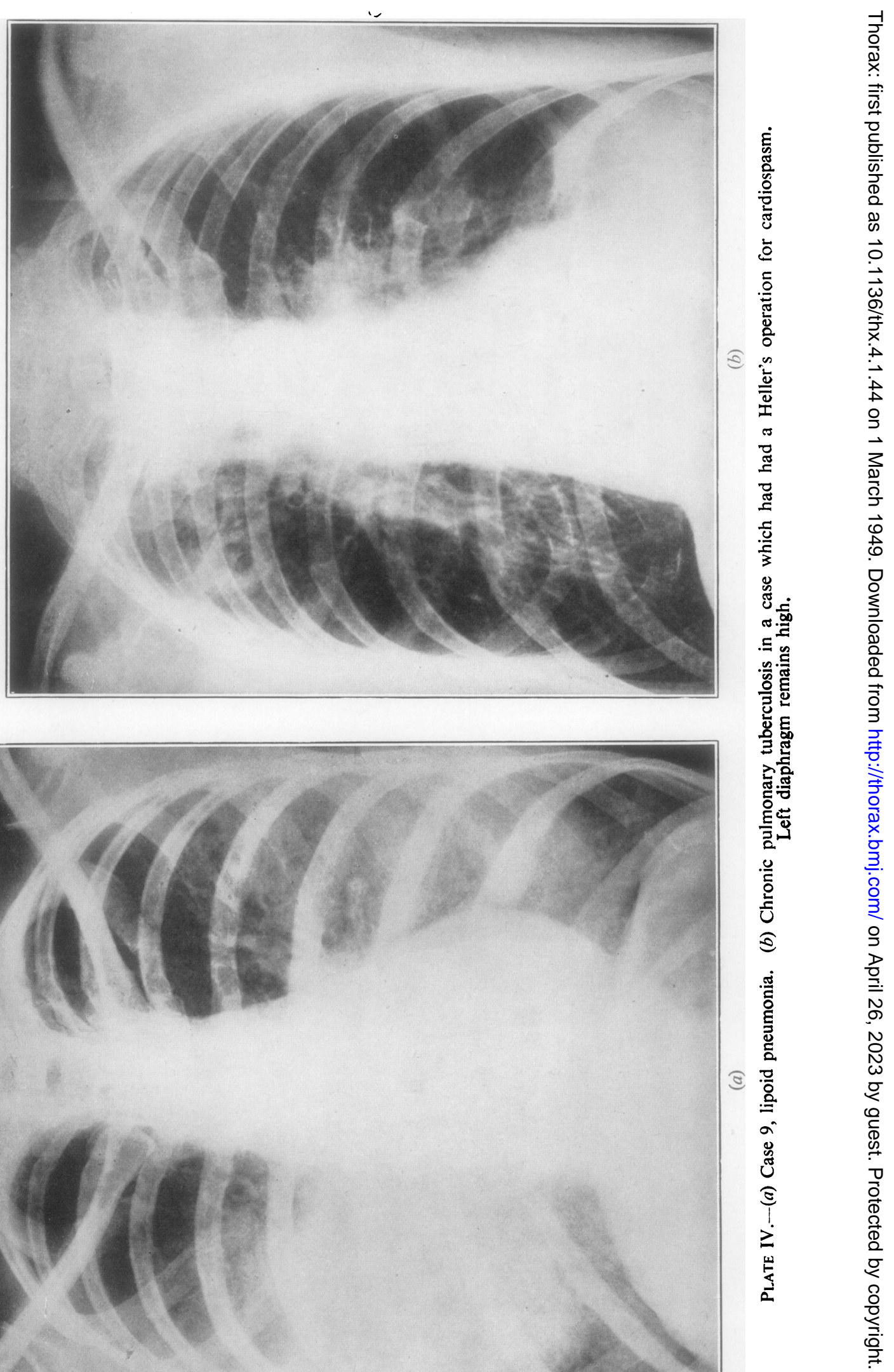
TABLE III

SUMMARY OF HISTORIES OF PATIENTS WITH PULMONARY FIBROSIS AND LIPOID PNEUMONIA

\begin{tabular}{|c|c|c|c|c|c|c|c|c|}
\hline \multicolumn{2}{|l|}{ Author } & Age & Sex & Cause & Effect & Site & $\begin{array}{l}\text { Course } \\
\text { and } \\
\text { comments }\end{array}$ & Presentation \\
\hline $\begin{array}{l}\text { Hawes ar } \\
\text { Soule }\end{array}$ & & 57 & $\mathbf{M}$ & Achalasia & Fibrosis & $\begin{array}{l}\text { Mid-zone max- } \\
\text { illary right }\end{array}$ & $\begin{array}{l}\text { One haemo- } \\
\text { ptysis }\end{array}$ & $\begin{array}{l}\text { Dysphagia and re- } \\
\text { gurgitation }\end{array}$ \\
\hline $\begin{array}{c}\text { Hawes ar } \\
\text { Soule }\end{array}$ & and & 31 & $\mathbf{M}$ & Achalasia & Fibrosis & Mid-zone & $\begin{array}{l}\text { No pulmon- } \\
\text { ary symptoms }\end{array}$ & $\begin{array}{l}\text { Dysphagia and re- } \\
\text { gurgitation }\end{array}$ \\
\hline Weens & . & 37 & $\mathbf{F}$ & Achalasia & Fibrosis & Maxillary right & No dysphagia & Productive cough \\
\hline Weens & . & 26 & $\mathbf{F}$ & Achalasia & Fibrosis & $\begin{array}{l}\text { Right maxil- } \\
\text { lary zone both } \\
\text { lower }\end{array}$ & Clubbing & $\begin{array}{l}\text { Dysphagia and re- } \\
\text { gurgitation }\end{array}$ \\
\hline Bird-Acosta & ta $\ldots$ & 39 & $\mathbf{M}$ & & & Mid-zone & $\begin{array}{c}\text { Aspirated via } \\
\text { bronchoscope }\end{array}$ & $\begin{array}{l}\text { Productive cough } 2 \\
\text { years }\end{array}$ \\
\hline $\begin{array}{l}\text { Warring ar } \\
\text { Rilance }\end{array}$ & and & 65 & $\mathbf{F}$ & Achalasia & Fibrosis & Maxillary right & Acid-fast bac- & $\begin{array}{l}\text { Dysphagia and re- } \\
\text { gurgitation } 19 \text { yrs. }\end{array}$ \\
\hline $\begin{array}{l}\text { Robson ar } \\
\text { Wilkinson }\end{array}$ & and & 13 & $\mathbf{F}$ & Achalasia & Fibrosis & $\begin{array}{l}\text { All zones max- } \\
\text { illary right }\end{array}$ & $\begin{array}{l}\text { Post-mortem } \\
\text { confirmation }\end{array}$ & $\begin{array}{l}\text { Dysphagia and re- } \\
\text { gurgitation } 6 \text { years }\end{array}$ \\
\hline Heaton & . & 51 & $\mathbf{F}$ & Achalasia & Fibrosis & $\begin{array}{l}\text { Mid-zones max- } \\
\text { illary right }\end{array}$ & $\begin{array}{l}\text { Previous his- } \\
\text { tory of ab- } \\
\text { scess }\end{array}$ & $\begin{array}{c}\text { Dysphagia and re- } \\
\text { gurgitation } 30 \text { yrs. }\end{array}$ \\
\hline Case 3 & . & 50 & $\mathbf{M}$ & Achalasia & Fibrosis & $\begin{array}{l}\text { Mid-zones max- } \\
\text { illary right }\end{array}$ & $\begin{array}{l}\text { Recent bron- } \\
\text { chitis }\end{array}$ & $\begin{array}{c}\text { Dysphagia and re- } \\
\text { gurgitation } 20 \text { yrs. }\end{array}$ \\
\hline Case 8 & . & 35 & $\mathbf{M}$ & Achalasia & Fibrosis & $\begin{array}{l}\text { Mid-zones max- } \\
\text { illary right }\end{array}$ & $\begin{array}{l}\text { Mega-oeso- } \\
\text { phagus and }\end{array}$ & $\begin{array}{l}\text { Cough and dys- } \\
\text { pnoea }\end{array}$ \\
\hline Case 9 & . & 19 & $\mathrm{~F}$ & Achalasia & $\begin{array}{l}\text { Lipoid pneu- } \\
\text { monia }\end{array}$ & Mid-zones & $\begin{array}{l}\mathrm{H} \text { is t or y of } \\
\text { use of liquid }\end{array}$ & Dysphagia 3 years \\
\hline Thomas & $\cdots$ & 32 & $\mathbf{M}$ & Achalasia & $\begin{array}{l}\text { Lipoid } \\
\text { pneumonia }\end{array}$ & $\begin{array}{l}\text { Right mid-zones } \\
\text { left base }\end{array}$ & $\begin{array}{l}\text { Recurrent } \\
\text { pneumonia }\end{array}$ & Dysphagia 4 years \\
\hline Wooler & . & 31 & $\mathbf{F}$ & Achalasia & $\begin{array}{l}\text { Lipoid } \\
\text { pneumonia }\end{array}$ & Left lower lobe & $\begin{array}{l}\text { Due to liquid } \\
\text { paraffin }\end{array}$ & $\begin{array}{l}\text { Dysphagia and re- } \\
\text { gurgitation }\end{array}$ \\
\hline Tcherthoff & . & 77 & $\mathbf{M}$ & Diverticulum & $\begin{array}{l}\text { Lipoid } \\
\text { pneumonia }\end{array}$ & Left lower lobe & $\begin{array}{l}\text { Improved, due } \\
\text { to excess milk }\end{array}$ & $\begin{array}{l}\text { "Bronchial carci- } \\
\text { noma" }\end{array}$ \\
\hline
\end{tabular}

led to residual fibrosis. Heaton's (1948) case had an old history of lung abscess, and several others either showed areas on their radiographs suggestive of cavity formation or had histories of febrile attacks associated with cough, sputum, and haemoptyses. The diagnosis has been radiological, the presence of fibrosis alone often giving rise to no symptoms or to a non-productive cough, febrile incidents being associated with superadded "pneumonitis" or abscess formation.

The characteristic radiological picture is one of bilateral mid-zone infiltration greater on the right than on the left, and often sharply demarcated below by the fissures (for example, Plates III $a$ and IV $a$ ) and maximal at the hilum.

The patient described by Robson and Wilkinson (1946) died after the performance of a Heller's operation; at necropsy the lungs showed widespread nodular fibrosis of all zones, reaching a maximum in the right upper lobe; this suggests that fibrosis may be more diffuse than is apparent radiologically. Fibrosis alone in this series had not given rise to much disability; dyspnoea and clubbing are recorded, but no cases have developed right heart failure.
Lipoid pneumonia.-Tcherthoff (1941) reviewed the 140 published cases of this disease; he stated that all were secondary to some form of defective swallowing and gave a long history of injections of some oily substance ; mineral oils in particular were responsible. In the final stages mid-zone fibrosis with an excess of oil in the lungs develops. He described one case in which the disease followed excessive ingestion of milk in a man of 77 suffering from a pharyngeal diverticulum. Two others have been described in association with achalasia; Case 9 in this series makes the total up to four. The radiological opacities which are iit the mid-zones (Plate IVa) are mainly due to fibrosis and the oily deposits are coincidental. These cases are examples of pulmonary fibrosis secondary to dysphagia with the added factor of a high fat content in the material retained in the oesophagus; sooner or later aspiration of this fatty material leads to the development of lipoid pneumonia.

Collapse.-There are two possible causes of collapse ; a large "bolus" may be aspirated causing flooding of a bronchus; this was responsible for the upper-lobe and lower-lobe collapse in Case 1. The alternative is that a bronchus becomes occluded by 
the dilated oesophagus pressing upon it from behind. Plummer and Vinson (1921) record cases with postprandial dyspnoea which in their opinion were due to dilatation of the oesophagus, and Bird-Acosta records an enormous mega-oesophagus causing a bulge in the posterior wall of the trachea which was observed at bronchoscopy. Wooler is of the opinion that the latter mechanism is responsible for the collapse, as re-expansion took place after dilatation of the cardiac sphincter in his case.

\section{Clinical Features}

Grey Turner (1946) has stated that achalasia of the cardia may present as a chronic cough. Examples have occurred in this series which presented as pulmonary disease with completely "silent" dysphagia, and there were others in which the pulmonary lesions were revealed only on routine radiography during investigation of dysphagia. Many intermediate examples have been reported. The patients in this series have been divided into three clinical groups: those who presented with major pulmonary and minor dysphagic symptoms; those who presented as dysphagia with subsequent development of pulmonary lesions; and a few cases in which these symptoms appeared almost simultaneously.

The patients with "silent dysphagia " constitute an important group. They may be defined as those who have a definite obstruction to normal deglutition but who have had no subjective difficulty in swallowing. There have been eight described, and unless it is recognized that mechanical obstruction of the oesophagus sufficient to lead to aspiration with consequent pulmonary lesions can exist without symptoms of which the patient is conscious, the real aetiology of the pulmonary lesion may be overlooked. Cases 4 and 7 are examples of " silent dysphagia," but in those described by Pruvost and Leblanc (1935) and Lallemant and Ordioni (1945) the oesophageal lesions were discovered fortuitously when transnasal bronchography was performed. In each, some of the iodized oil went past the glottis ; in the first a hitherto unsuspected pharyngeal diverticulum, in the second an achalasia of the cardia which had been symptomless, became apparent. Both these patients had presented with right upper-lobe lung abscesses.

Asymptomatic pulmonary lesions are of less importance, but the presence of radiolog:cal changes in the lung fields in association with dysphagia makes active treatment of the latter more necessary in order that serious pulmonary lesions may be avoided. The presence of bilateral mid- zone fibrosis in association with achalasia was $\overline{0}$ recognized in a case described by Hawes and $\frac{C}{O}$ Soule (1945), and it was not until two years later क that an haemoptysis with purulent foetid sputum $\mathbb{}$ developed.

Eighteen patients presented with predominantly $\vec{\circ}$ pulmonary symptoms. The eight "silent dys-? phagias" are included in this number, and the $\vec{\omega}$ remaining ten had varying degrees of dysphagia, o but often they had become accustomed to $\vec{x}$ dysphagia and only admitted its presence on questioning.

A long-standing cough in association with the dysphagia has been a frequent feature, and it may be the only clinical indication of a pulmonary $\vec{r}$ lesion. Jackson and Jackson (1933) are of the opinion that there is a "tussive centre" at the lower end of the oesophagus, and that any lesion or pressure from a column of liquid on this area $\varphi$ may be responsible for a reflex cough. It is also probable that even in the early stages of achalasia small aspirations take place which cause tracheobronchitis and an irritating cough. In the four cases in which the onset of pulmonary and dysphagic symptoms has been simultaneous, this $\mathbb{Q}$ mechanism may have been responsible for the early development of the cough.

The remaining twenty-six cases presented with predominantly dysphagic symptoms, although in several the onset of the pulmonary disease was responsible for their seeing a doctor. In four the으 lung les:on was symptomless and was discovered $\underset{\times}{\mathscr{Q}}$ by the radiologist.

Freeman (1940), discussing the symptomatology of achalasia, states that the average length of $O$ history is five years and that the predominant symptoms are dysphagia, pain, and regurgitation.을 In this series the dysphagia has often been mini- $\rightarrow$ mal or periodical, despite the presence of enormous mega-oesophagus. Regurgitation, which Freeman o regards as a late symptom, has been common; it has often been associated with nocturnal cough and choking, and has been recorded eighteencw times. Plummer and Vinson (1921) mention regurgitation as occurring in eighty-nine of $30 \mathrm{k}$ cases of achalasia.

Where the length of history of dysphagia in patients suffering from achalasia and with pharyngeal diverticula has been given, it has averaged ten years prior to the onset of pulmonary symp $\frac{\text { ? }}{\mathbb{D}}$ toms. Pulmonary lesions may therefore beo regarded as a late complication; but aspiration phenomena complicating carcinomata and stric $\Omega$ tures appear more rapidly. 
TABLE IV

SUMMARY OF HISTORIES OF PATIENTS SUFFERING FROM BRONCHIECTASIS

\begin{tabular}{|c|c|c|c|c|c|c|c|}
\hline Author & Age & Sex & Cause & Effect & Site & $\begin{array}{c}\text { Course } \\
\text { and } \\
\text { comments }\end{array}$ & Presentation \\
\hline Schrier & 12 & $\mathbf{F}$ & Achalasia & Bronchiectasis & $\begin{array}{c}\text { Right middle } \\
\text { and lower } \\
\text { lobes }\end{array}$ & $\underset{\text { phagia }}{\text { Silent dys- }}$ & $\begin{array}{l}\text { Productive cough } 6 \\
\text { years }\end{array}$ \\
\hline Wooler & 18 & $\mathbf{F}$ & Achalasia & Bronchiectasis & Bilateral & $\underset{\text { phagia }}{\text { Minimal dys- }}$ & $\begin{array}{l}\text { Pneumonia, cough } \\
5 \text { years }\end{array}$ \\
\hline Weens & 28 & $\mathbf{F}$ & Achalasia & Bronchiectasis & $\begin{array}{l}\text { Bilateral lower } \\
\text { lobes }\end{array}$ & $\begin{array}{l}\text { Mega-oeso- } \\
\text { phagus }\end{array}$ & $\begin{array}{l}\text { Productive cough } \\
15 \text { years }\end{array}$ \\
\hline Reeke & 19 & F & Achalusia & Bronchiectasis & $\begin{array}{l}\text { Bilateral lower } \\
\text { lobes }\end{array}$ & $\begin{array}{l}\text { Simultaneous } \\
\text { onset }\end{array}$ & $\begin{array}{l}\text { Dysphagia and re- } \\
\text { gurgitation since } \\
\text { infancy }\end{array}$ \\
\hline $\begin{array}{l}\text { Chabrol and } \\
\text { Cachin }\end{array}$ & 46 & $\mathbf{M}$ & $\begin{array}{l}\text { Peptic ulcer } \\
\text { of oesopha- } \\
\text { gus }\end{array}$ & Bronchiectasis & $\begin{array}{l}\text { Right lower } \\
\text { lobe }\end{array}$ & Coughs 1 year & Dysphagia 2 years \\
\hline Case 7 & 6 & $\mathbf{F}$ & Achalasia & Bronchiectasis & $\begin{array}{l}\text { Right middle } \\
\text { upper lower } \\
\text { lobes, left lin- } \\
\text { gular }\end{array}$ & $\begin{array}{l}\text { Silent dys- } \\
\text { phagia }\end{array}$ & Pneumonia \\
\hline
\end{tabular}

Two groups appear to be clinically separate from the majority of the cases. Those which have been associated with bronchiectasis have almost all occurred in young people (five out of six), and in several it was difficult to determine whether or not the dysphagia, which in three was almost silent (Case 7), preceded the bronchiectasis. The average age for onset of symptoms was six years and of presentation 20, whereas in the remainder of this series the average age of presentation was 43 years. The bronchiectasis had the usual distribution in the lower and middle lobes, and it is possible that aspiration which in adults is liable to produce lung abscess gives rise to bronchiectasis in younger patients. In the second group the pulmonary lesions have been associated with acid-fast bacilli in the sputum. It is not stated whether or not the three cases of pulmonary tuberculosis referred to by Plummer and Vinson in relation to achalasia were confirmed on culture and guinea-pig inoculation. The first case in which acid-fast bacilli were found and were recognized as being non-tuberculous was described by Cummins and Williams (1933); since then there have been three more in the literature. Cases 2 and 5 in this series make the total six. All except Case 5 were secondary to achalasia.

The bacilli which Cummins and Williams isolated were non-pathogenic to guinea-pigs. In Baldwin's (1942) case the acid-fast bacilli were non-pathogenic and were found in both vomit and sputum. A "tuberculin" was made from the organisms to which the patient gave a markedly positive reaction, but despite this the organism was considered to be non-pathogenic and was thought to be related to the Timothy grass bacillus. Warring and Rilance (1943) described the next case ; the clinical and radiological findings were similar to Baldwin's and to Case 2 ; the "tuberculin" reaction was positive. The third case was reported by Rothstein and Pirkle (1946); the patient was "tuberculin" positive, but negative to the standard tuberculin tests. The radiographs of two of the patients in whose sputa acid-fast bacilli were found showed cavitation; in the other two the films were similar to that shown in Plate III $a$.

The feature which originally led to the suspicion that the patients were not tuberculous was the presence of few or occasional "showers" of organisms, with persistent copious sputum. Where follow-ups are available the pulmonary lesions have either cleared up completely or have left residual fibrosis in the mid-zones. The cough and sputum have been considerably relieved by the treatment of the dysphagia. Case 2, diagnosed at first as suffering from pulmonary tuberculosis, now shows a clear radiograph (Plate II $b$ ), and was certainly never tuberculous. Case 5 is still doubtful ; the acid-fast bacilli were found on only one occasion and were not cultured. $\mathrm{He}$ is almost symptom-free and is assumed to be nontuberculous.

The acid-fast bacilli are derived from the oesophagus, possibly from fruit skins; they are aspirated into the bronchial tree and are non- 
TABLE V

CAUSES AND CONSEQUENCES OF DYSPHAGIA IN THE PRESENT SERIES

\begin{tabular}{|c|c|c|c|c|c|c|c|}
\hline & Number & Abscess & Bronchiectasis & Fibrosis & Pneumonitis & Collapse & $\begin{array}{l}\text { Lipoid } \\
\text { pneumonia }\end{array}$ \\
\hline $\begin{array}{l}\text { Achalasia } \\
\text { Pharyngeal diverticulum } \\
\text { Carcinoma of oesophagus } \\
\text { Various strictures }\end{array}$ & $\begin{array}{r}34 \\
5 \\
3 \\
6\end{array}$ & $\begin{array}{l}9 \\
3 \\
3 \\
3\end{array}$ & $\frac{4}{2}$ & $\frac{10}{-}$ & $\frac{6}{1}$ & $\frac{2}{=}$ & $\begin{array}{l}3 \\
1 \\
-\end{array}$ \\
\hline Total & 48 & 18 & 6 & 10 & 8 & 2 & 4 \\
\hline
\end{tabular}

pathogenic. The pulmonary lesions they produce are similar to those of pneumonitis in which no acid-fast bacilli have been demonstrated, and the finding of the organism is coincidental. The association of pulmonary tuberculosis with megaoesophagus is sufficiently uncommon to have been reported when it has occurred, and it is suggested that when aspiration pneumonitis appears the diagnosis of tuberculosis should be confirmed by culture or guinea-pig inoculation. Achalasia and pulmonary tuberculosis can co-exist as in the case illustrated (Plate IV $b$ ) ; this man had had six years of recurrent pulmonary symptoms prior to an acute onset of achalasia.

The causes of dysphagia and their consequences in this series are shown in Table $\mathrm{V}$.

\section{SUMMARY}

1. Forty-eight cases of "dysphagia pneumonitis" have been collected. Their incidence, aetiology, clinical presentation, and pathology have been discussed.

2. In association with dysphagia, pneumonitis is due to small sporadic aspirations; pulmonary abscess to a major spill of oesophageal contents ; fibrosis to a prolonged period of small aspirations ; and lipoid pneumonia to this type of aetiology with the addition of a high fat content in the retained oesophageal material.

3. "Silent dysphagia" is a possible cause of pulmonary lesions of obscure origin.

4. Acid-fast bacilli found in the sputum of patients with mechanical dysphagia should be regarded as non-pathogenic until proved otherwise.

5 . The end result of the syndrome is most frequently pulmonary fibrosis.

My gratitude is due to the members of the honorary staff of the Brompton Hospital who have provided the material for the new cases described and who have been helpful with their advice and criticisms.

\section{REFERENCES}

Baldwin, E. R. (1942). Amer. Rev. Tuberc., 45, 756. Bird-Acosta, I. (1944). Amer. J. Roentgen., 52, 481.

Brock, R. C. (1946). "Anatomy of the Bronchial Tree." London.

Camiel, M. R., and Loewe, L. (1941). Ann. int. Med., $15,63$.

Chabrol, E., and Cachin, M. (1933). Bull. Nem. Soc Med. Hosp., Paris, 49, 1531.

Cummins, S. L., and Williams, E. M. (1933). Tubercle, $15,49$.

Eley, A. J. (1948). Personal communication.

Freeman, E. B. (1940). Rev. Gastroenterol., 7, 385.

Hallé, J., and others (1930). Arch. Méd. Enfants, 33, 670.

Harrington, S. W. (1945). Surgery, 18, 66.

Hawes, L. E., and Soule, A. B. (1945). Amer. J. Roentgen., $53,124$.

Heaton, T. G. (1948). Dis. Chest., 14, 425.

Jackson, C., and Jackson, C. L. (1933). Sect. Otolaryngol. A.M.A., p. 197.

Keefer, C. S. (1934). Ann. int. Med., 8, 72.

Lahey, F. H. (1946). Amer. Surg., 124, 617.

Lallemant, M., and Ordioni, P. (1945). Ann. d'otolaryngol., 12, 284.

Mallory, T. B. (1938). New Engl. J. Med., 218, 607.

Negus, V. E. (1942). Proc. R. Soc. Med., 36, 85.

Plummer, H. S., and Vinson, P. P. (1921). Med. Clin. N. Amer., 5, 355.

Pruvost, P., and Leblanc, M. (1935). Arch. méd.-chir. Appar. resp., 10, 242.

Reeke, T. (1933). Dtsch. Z. Chirg., 241, 488.

Robson, T., and Wilkinson, R.S. (1946). Lancet, 1, 737.

Rothstein, E., and Pirkle, H. B. (1946). Dis. Chest., 12, 232.

Sampson, D. A. (1938). New Engl. J. Med., 219, 982.

Schrier, T. (1938). Lancet, 2, 1225.

Sergent, E. (1937). Rev. gen. Clin. Therap. J. Pract., 51, 497.

Sergent, E., Poumeau, Delille-G. (1934). Paris Méd., 1, 154.

Tcherthoff, I. (1941). Quart. Bull. Sea View Hosp., 7, 334.

Thomas, C. Price (1948). Personal communication.

Thomas, W.S., and Jewett, C. H. (1936). Clift. med. Bull., 12, 130.

Tucker, G. (1933). Sect. Otolaryngol. A.M.A., p. 197. Turner, G. Grey (1946). "Injuries and Diseases of the Oesophagus." London.

Vinson, P. P. (1927). Amer. J. Surg., 2, 359.

Warring, F, C., and Rilance,'A. B. (1943). J. Lab. clin. Med., 28, 1591.

Weens, H. S. (1944). Amer. J. Roentgen., 52, 472.

Wooler, S. (1948). Thorax, 3, 53. 